\title{
HUBUNGAN AKSESIBILITAS TERHADAP TINGKAT PERKEMBANGAN WILAYAH DESA DI KECAMATAN TAMBUN SELATAN KABUPATEN BEKASI
}

\author{
(Relationship Between Accessibility to The Development Level of Village Areas in Tambun Selatan \\ District, Bekasi Regency)
}

\author{
Alif Fikri Nurhidayani ${ }^{1}$, Prima Jiwa Osly ${ }^{1}$, Irfan Ihsani ${ }^{1}$ \\ ${ }^{1}$ Program Studi Teknik Sipil Universitas Pancasila \\ E-mail: aliffikri164@gmail.com
}

\begin{abstract}
ABSTRAK
Pengembangan wilayah merupakan salah satu cara untuk mencapai keberhasilan pengembangan wilayah. Dengan adanya pembangunan infrastruktur yang terus menerus, sistem jaringan suatu wilayah, lingkungan kehidupan didalamnya dan kesejahteraan manusia dapat mempegaruhi suatu perkembangan wilayah tersebut. Penelitian ini bertujuan untuk mengetahui hubungan aksesibilitas yang didalamnya dipengaruhi sistem jaringan jalan dan perkembangan wilayah perdesaan di kecamatan Tambun Selatan kabupaten Bekasi. Untuk menjawab tujuan penelitian ini digunakan analisis indeks alfa untuk mengetahui tingkat aksesibilitas wilayah tersebut, analisis skalogram untuk mengetahui tingkat perkembangan wilayah tersebut dan analisis korelasi untuk mengetahui hubungan antara kedua variabel tersebut. Berdasarkan perhitungan yang dilakukan, desa yang memiliki tingkat aksesibilitas paling tinggi adalah desa Tambun dengan nilai -0,023 dan desa yang paling rendah adalah desa Lambangsari dengan nilai 0,270. Sedangkan untuk tingkat perkembangan wilayah, desa Tambun merupakan desa yang memiliki tingkat perkembangan wilayah yang paling tinggi dengan nilai range 266,94 dan mendapatkan kategori hierarki 1 dan desa Lambangjaya merupakan desa yang paling rendah tingkat perkembangan wilayah dengan nilai range 115 dan mendapatkan kategori hierarki 3. Berdasarkan output (hasil) perhitungan antara aksesibilitas wilayah dan perkembangan wilayah dapat diketahui bahwa nilai korelasi antara dua variabel ini adalah sebesar 0.738. Angka tersebut menunjukkan bahwa hubungan antara dua variabel ini termasuk dalam kategori hubungan erat karena nilai $r$ diantara nilai $0.7-0.9$. Berdasarkan hasil dari penelitian yang telah dilakukan, ada beberapa saran yang dihasilkan yaitu pertama, pemerataan jaringan jalan di desa yang memiliki nilai aksesibilitas rendah. Kedua adalah pemerataan pembangunan yang memiliki peran fital dalam perkembangan wilayah seperti fasilitas pendidikan, fasilitas kesehatan, fasilitas perindustrian, fasilitas peribadatan di kecamatan yang memiliki nilai perkembangan rendah.
\end{abstract}

Kata Kunci : Aksesibilitas, Perkembangan Wilayah, Skalogram

\begin{abstract}
This study aims to determine the relationship of accessibility in which is influenced the system of road network and the development of rural areas in Tambun Selatan district of Bekasi district. To answer the purpose of this study used alpha index analysis to determine the level of accessibility of the region, scalogram analysis to determine the level of regional development and correlation analysis to determine the relationship between the two variables. Based on the calculations performed, the village with the highest level of accessibility is Tambun village with a value of -0.023 and the lowest village is Lambangsari village with a value of 0.270. As for the level of regional development, Tambun village is a village that has the highest level of regional development with a value range of 266.94 and get the category hierarchy 1 and Lambangjaya village is the lowest village level development with a range of 115 and get the category hierarchy 3. Based on the output (outcome) calculation between area accessibility and regional development can be seen that the correlation value between these two variables is 0.738 . This number indicates that the relationship between these two variables belongs to the category of close relationship because the $r$ value is between $0.7-0.9$.
\end{abstract}

Keywords : Accessibility, Regional Development, Skalogram 


\section{PENDAHULUAN}

Pembangunan pada dasarnya merupakan salah satu wujud dari tugas pelayanan yang dilaksanakan oleh perintah dalam rangka memenuhi kebutuhan masyarakat umum. Ini berarti bahwa pembangunan merupakan implementasi dari tugas pelayan. Sehubungan dengan hal tersebut, dalam melaksanakan kegiatan pembangunan. Pertimbangan atas upaya pemenuhan kebutuhan masyarakat luas harus menjadi perhatian utama. Oleh karena itu, salah satu indikator utama untuk melihat/mengukur berhasil tidaknya suatu proses pembangunan adalah sampai sejauh mana atau seberapa besar tingkat kebutuhan masyarakat dapat terpenuhi, baik secara langsung maupun tidak langsung.

Pengembangan wilayah perkotaan merupakan upaya pembangunan yang dilakukan secara terus menerus agar tercapai kualitas kesejahteraan masyarakat dan lingkungan hidup di dalamnya. Terdapat dua aspek yang mempengaruhi perkembangan suatu wilayah perkotaan yaitu aspek fisik seperti letak geografis yang strategis dan aspek sosial seperti potensi sosial ekonomi yang dimiliki wilayah tersebut. Pengembangan wilayah perkotaan harus dilakukan secara komprehensif, dimana di dalamnya termasuk juga pengembangan wilayah kecamatan dan desa.

Salah satu indikator yang mendukung pengembangan wilayah kecamatan adalah ketersediaan infrastruktur dan sistem jaringan di wilayah tersebut. Ketersediaan infrastruktur seperti sarana dan prasarana dianggap sebagai faktor potensial dalam menentukan masa depan dari perkembangan suatu wilayah. Selain itu banyaknya sistem jaringan jalan dalam suatu wilayah akan mempengaruhi nilai aksesibiltas dalam wilayah tersebut. Aksesibilitas wilayah adalah kemampuan atau keadaan suatu wilayah untuk dapat diakses oleh pihak luar baik secara langsung atau tidak langsung. Aksesibilitas yang baik akan melancarkan interaksi masyarakat antar wilayah sehingga terjadi pemerataan pembangunan.

Tujuan penelitian ini adalah: :

1. Menghitung nilai aksesibilitas pada tiap desa di kecamatan Tambun Selatan.

2. Analisis skalogram sebagai parameter perkembangan wilayah di kecamatan Tambun Selatan.

3. Menghitung nilai korelasi antara aksesibilitas dan perkembangan wilayah pada wilayah di kecamatan Tambun Selatan.

Aksesibilitas wilayah adalah kemampuan atau keadaan suatu wilayah untuk dapat diakses oleh pihak luar baik secara langsung atau tidak langsung. Aksesibilitas tersebut terdiri dari prasarana (sistem jaringan jalan) yang ada beserta ketersediaan sarana untuk melakukan pergerakannya. Salah satu variabel yang dapat menyatakan tinggi atau rendahnya suatu aksesibilitas wilayah dalam suatu daerah adalah dengan melihat banyaknya sistem jaringan jalan yang tersedia pada daerah tersebut.

Pengukuran Aksesibilitas suatu wilayah tidak lepas dari ketersediaan sarana transportasi yaitu jaringan jalan. Untuk pengukuran indeks aksesibilitas pada suatu wilayah, dalam penelitian ini menggunakan cara dengan membandingkan antara jumlah jaringan jalan dalam suatu wilayah dengan wilayah yang lain.

Pengembangan wilayah merupakan upaya untuk memacu perkembangan sosial ekonomi, penurunan kesenjangan antar wilayah dan pemeliharaan kelestarian lingkungan hidup di suatu wilayah. Upaya ini diperlukan karena setiap wilayah memiliki kondisi social ekonomi, budaya dan keadaan geografis yang berbeda-beda, sehingga pengembangan wilayah bertujuan untuk mengoptimalkan potensi yang dimiliki oleh suatu wilayah (Bratakusumah, 2005).

Sesuatu wilayah selalu mengalami perkembangan dari waktu ke waktu. salah satu indikator perkembangan wilayah adalah kemudahan. Kemudahan dalam hal ini terkait dengan cara masyarakat memperoleh kebutuhan baik kebutuhan sehari-hari.

Prasarana (infrastruktur) merupakan hal yang penting dalam meningkatkan perkembangan sosial dan kegiatan ekonomi. Pembangunan tidak akan berjalan lancar jika prasarana tidak baik. Aspek prasarana pembangunan yang berkelanjutan dari berbagai bidang antara lain, Pendidikan, Kesehatan, Banyaknya Industri, Jenis Perdagangan dan Peribadatan (Adisasmita, 2010).

Analisis skalogram dilakukan untuk mengetahui pusat pelayanan berdasarkan jumlah dan jenis unit fasilitas pelayanan yang ada di dalam setiap daerah. Asumsi yang dipakai adalah bahwa wilayah yang memiliki ranking tertinggi adalah lokasi yang dapat ditetapkan menjadi pusat pertumbuhan (Yamin, 2008).

Dalam penentuan hierarki pelayanan fasilitas sarana dan prasarana dilihat dari orde yang didapat dari analisis skalogram. Perhitungan skalogram dijabarkan dalam tabel yang berisi fasilitas-fasilitas sarana dan prasarana perkecamatan. Adanya fasilitas sarana dan prasarana ditandai dengan angka 1 sedangkan angka 0 menunjukan yang tidak memiliki fasilitas.

Analisis Skalogram pada umunya dipergunakan untuk menganalisis pusat-pusat permukiman, kususnya hirarki atau orde pusat-pusat permukiman. Analisis ini untuk memberikan gambaran adanya peneglompokkan permukiman sebagai pusat pelayanan dengan mendasarkan pada kelengkapan fungsi pelayanannya. Fasilitas yang digunakan pada penilaian ini adalah fasilitas yang mencirikan fungsi pelayanan sosial dan ekonomi dengan kriteria obyek tunggal dan terukur serta sedapatnya memiliki karakteristik hirarkis atau berjengjang (Anisa, 2013). 


\section{METODE}

Dalam penelitian ini menggunakan jenis penelitian deskriptif. Objek yang akan dijelaskan dalam penlitian ini adalah tingkat aksesibilitas wilayah, tingkat perkembangan wilayah, kemudian akan dilihat hubungan antara dua variabel penelitian ini.

\section{Lokasi penelitian}

Pemilihan lokasi wilayah penelitian tersebut dengan pertimbangan bahwa kawasan ini adalah kawasan yang cukup luas dengan kecamatan yang cukup cepat pertumbuhan penduduknya. Dengan pertumbuhan penduduk yang relatif cepat diiringi pembangunan sarana dan prasarana yang memadai. Pertumbuhan penduduk ini akan mempengaruhi tingkat aksesibilitas jaringan jalan yang dapat menimbulkan masalah baru, diantaranya akan terjadi kemacetan diakibatkan oleh dampak pertumbuhan penduduk. Wilayah pada penelitian ini adalah Tambun Selatan dan dapat dilihat pada gambar 1 .

Wilayah pada penelitian ini berada pada Kecamatan Tambun Selatan. Dimana kecamatan ini masuk dalam lingkup wilayah kabupaten Bekasi, salah satu kecamatan dari 23 kecamatan di Kabupaten Bekasi. Jumlah penduduk kecamatan Tambun Selatan 417.008 jiwa. Kecamatan Tambun Selatan mempunyai Luas $43,10 \mathrm{~km}^{2}$ terdiri dari 1 kelurahan dan 9 desa yaitu desa Jatimulya, desa Lambangsari, desa Lambangsari, desa Mangunjaya, desa Mekarsari, desa Setiamekar, desa Sumberjaya, desa Tambun, desa Tridaya.

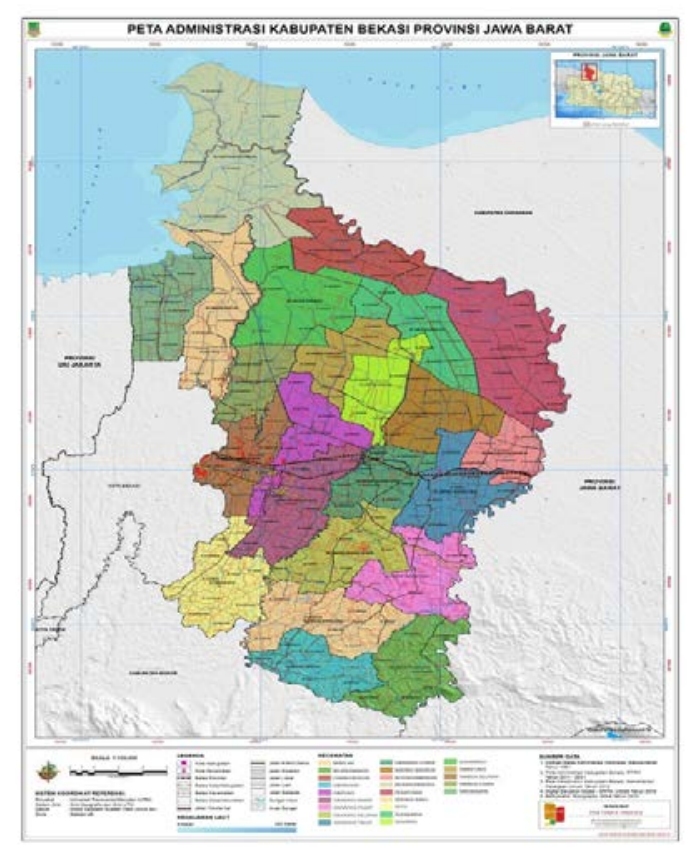

Gambar 1. Peta Kabupaten Bekasi.

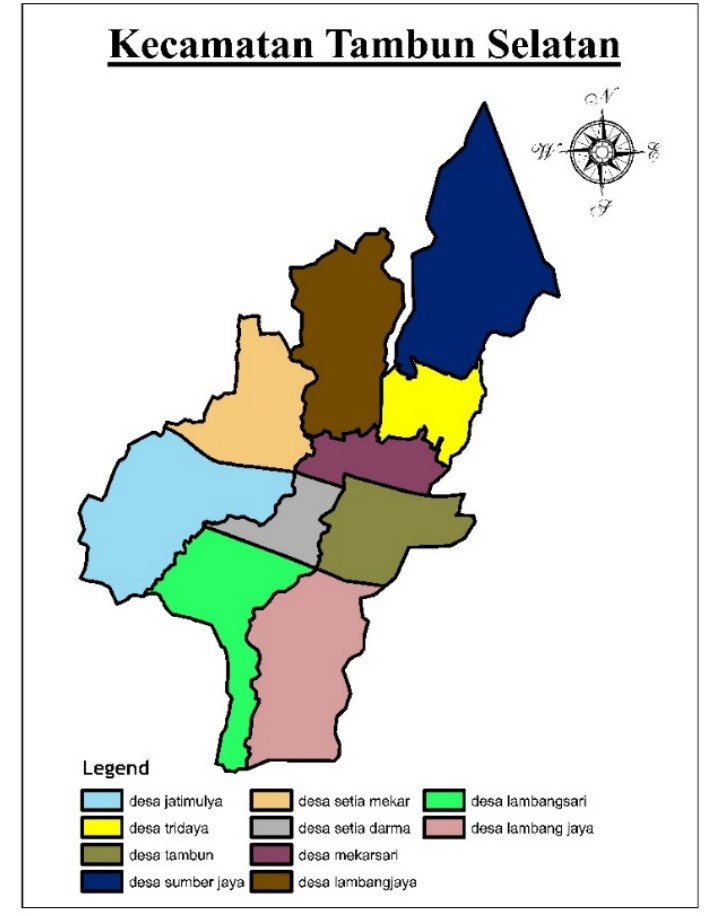

Gambar 2. Batasan wilayah kecamatan Tambun Selatan.

Gambar 2 diatas didapatkan menggunakan aplikasi arcgis yang dipeta-petakan setiap desa sehingga mendapatkan batasan-batasan wilayah perdesa pada kecamatan Tambun Selatan. Pada tabel 3.1 dibawah ini dapat dilihat batasan wilayahnya.

\section{Metode analisis data}

Teknik data yang digunakan untuk menjawab tujuan penelitian diantaranya adalah aksesibilitas wilayah dan analisis skalogram selanjutnya dua data tersebut dikolerasikan. Penjelasan tersebut dijelaskan dibawah ini.

Data penelitian ini di dapat dari Badan Statistik kabupaten Bekasi tahun 2016 dan sumber data yang dicari adalah fasilitas pendidikan, fasilitas kesehatan, fasilitas perdagangan, fasilitas peridustrian, dan fasilitas perdagangan untuk mendapatkan perhitugan skalogram.

- Metode aksesibilitas wilayah

Perhitungan tingkat aksesibilitas wilayah menggunakan rumus indeks alpha. Perhitungan dengan menggunakan rumus indeks alpha adalah untuk mengetahui konektivitas suatu graf (jaringan jalan) terhadap suatu daerah dengan daerah lainnya. Rumus indeks alpha adalah sebagai berikut :

$$
\operatorname{Alpha}(a)=\frac{m-t+s}{2 t-s}
$$

Keterangan :

$\begin{array}{ll}\text { Alpha (a) } & =\text { Tingkat Aksesibilitas } \\ \mathrm{M} & =\text { Jaringan Jalan (graf) } \\ \mathrm{T} & =\text { Titik Tempat (simpul) } \\ \mathrm{S} & =\text { Wilayah (sub graf) }\end{array}$


Interpretasi dari indeks alfa adalah jika nilai indeks alfa mendekati 1 maka nilai semakin tinggi atau tingkatan aksesibilitasnya tinggi.

- $\quad$ Metode perkembangan wilayah

Analisis skalogram dilakukan untuk mengetahui pusat pelayanan berdasarkan jumlah dan jenis unit fasilitas pelayanan yang ada di dalam setiap daerah. Asumsi yang dipakai adalah bahwa wilayah yang memiliki ranking tertinggi adalah lokasi yang dapat ditetapkan menjadi pusat pertumbuhan.

Dalam penelitian ini, data yang digunakan untuk menganalisis meliputi data jumlah sarana pendidikan, kesehatan, peribadatan, dan data penunjang lainnya. Secara spesifikasi data fasilitas yang digunakan antara lain SD, MI SLTP, MTS, SMA,MA SMK, Puskesmas, Pusat Rawat Inap, RSU, Perindustrian dan Peribadatan.

Teknik analisis yang digunakan dalam analisis skalogram ini dengan cara membuat sesuatu tabel yang mengurutkan ketersediaan fasilitas suatu wilayah yang diidentifikasi sebagai pusat pelayanan. Untuk menguji kelayakan skalogram digunakan persamaan Coeffisien of Reproducibility (COR). Apabila hasil perhitungan reproduksibilitas (COR) $>90 \%$ maka hasil perhitungan skalogram tersebut dapat diterima dan digunakan untuk dasar analisis lebih lanjut. Adapun rumus perhitungan skalogram adalah sebagai berikut :

$$
\text { Bobot Skalogram }=\frac{\text { Sentralitas }(100)}{\text { Jumlah Fasilitas }}
$$

Dan menggunakan rumus kelas interval :

$$
\text { Kelas Interfal }=\frac{\text { Nilai Tertinggi }- \text { Nilai Terendah }}{\text { Jumlah Klasifikasi }}
$$

- Metode analisis korelasi

Untuk mengetahui hubungan antara aksesibilitas wilayah dengan perkembangan wilayah digunakan metode analisis korelasi dengan bantuan spss. Besarnya koefisiensi korelasi sebagai berikut :

$$
r=\frac{N \Sigma x y-\Sigma x \Sigma y}{\sqrt{\left[\Sigma x_{1}{ }^{2}-\left(\Sigma x_{1}\right)^{2}\right]\left[N \Sigma y_{1}{ }^{2}-\left(\Sigma y_{1}\right)^{2}\right]}}
$$

Keterangan :

(Pambudu, 2005)

$r=$ koefisien korelasi

$x=$ Aksesibilitas wilayah

$\mathrm{y}=$ Perkembangan kecamatan/kabupaten/kota

$\mathrm{n}$ = Jumlah kecamatan/kabupaten/kota

Nilai $r$ berkisar antara -1 sampai 1

Interpretasi nilai $r$ adalah jika $r$ mendekati 0 maka hubungan dua variabel sangat lemah atau tidak ada hubungan sama begitu juga sebaliknya jika nilai $r$ atau -1 maka hubungan kedua variabel sangat kuat.
Adapun untuk mempermudah dalam pembuatan analisis ini, maka diperlukan pembuatan diagram alir seperti dibawah ini :

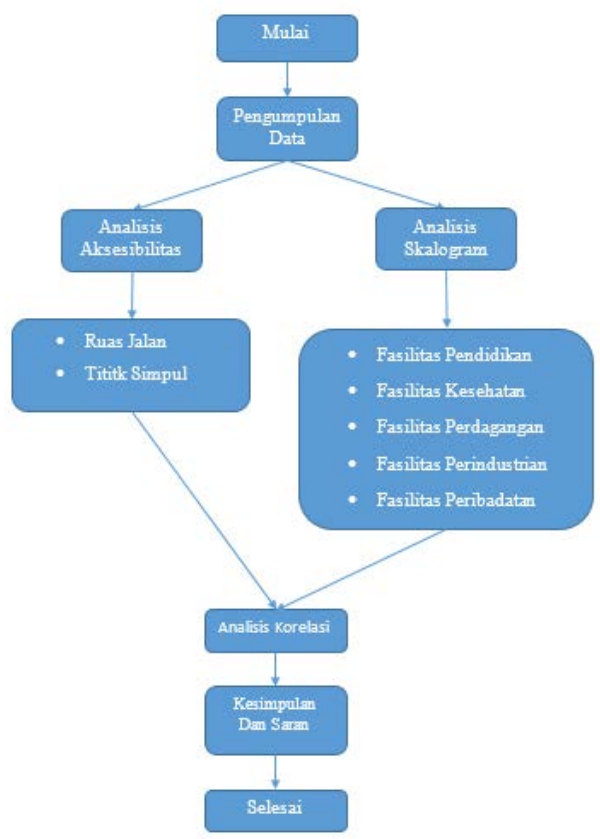

Gambar 2. Diagram Alir Peneitian

\section{HASIL DAN PEMBAHASAN}

1. Analisis aksesibilitas wilayah

Analisis aksesibilitas dalam pengambilan data ini menggunakan data-data dari peta Rupa bumi Indonesia (RBI) tahun 2016. Data ini memiliki data yang cukup lengkap diantaranya penutupan lahan, hidrografi, hiprografi, bangunan, batas administrasi toponim, transportasi dan utilitas Salah satunya jaringan jalan. dan aplikasi yang digunakan adalah aplikasi Arcgis karena aplikasi ini merupakan software yang paling mutakhir.

Data yang didapat dari peta rupa bumi Indonesia tahun 2016 di plot berdasarkan batas administrasi perdesa di Kecamatan Tambun Selatan yang didapatkan dari Google Earth Pro dan selanjutnya data-data tersebut di peta kan menjadi 10 desa pada kecamatan Tambun Selatan dengan menggunakan software dapat dilihat pada Gambar 3 dibawah ini.

\section{Diagram alir}




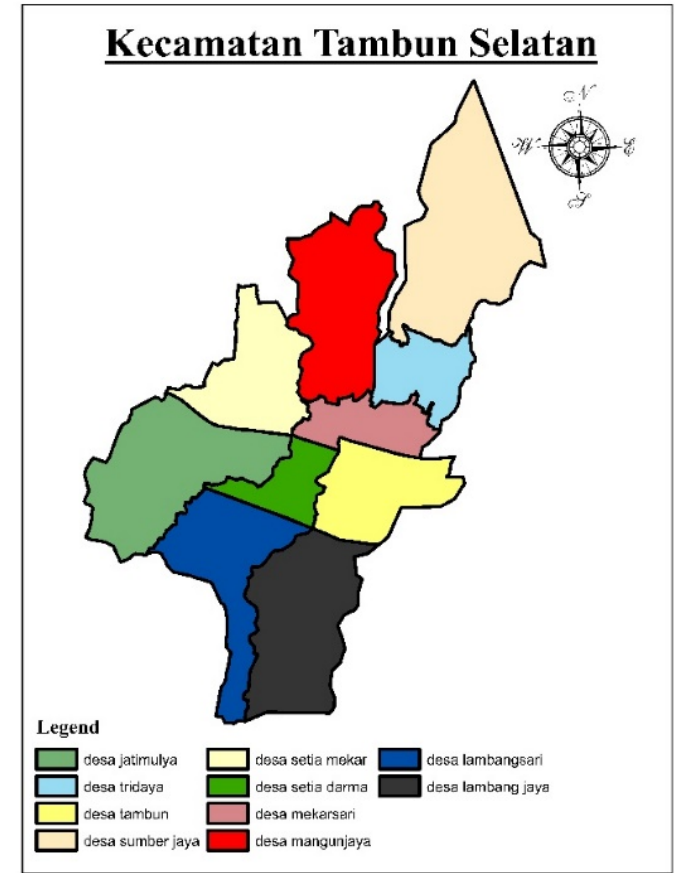

Gambar 3. Wilayah desa kecamatan Tambun Selatan Tahun 2016.

Selanjutnya data-data tersebut di peta kan menjadi 10 desa pada kecamatan Tambun Selatan dengan menggunakan software. Setelah mendapatkan nilai data ruas jalan dan data titik simpul selanjutnya menghitung nilai aksesbilitas wilayah dengan cara dibawah ini.

$$
\operatorname{Alph} a(a)=\frac{m-t+s}{2 t-s}
$$

Maka dengan rumus diatas dapat ditemukan nilai indeks alfa dari setiap desa dan mendapatkan hasilnya. Setelah mendapat nilai Indeks Alfa dari setiap desa yang ada di Kecamatan Tambun Selatan, langkah selanjutnya adalah mengklasifikasikan nilai indeks alfa perdesa. Perhitungan pengklasifikasian nilai indeks alfa, menggunakan rumus interval sebagai berikut.

$$
\begin{aligned}
& \text { Kelas Interval } \\
& =\frac{\text { Nilai Maksimum }- \text { Nilai Minimum }}{\text { Jumlah Kelas Yang Diinginkan }}
\end{aligned}
$$

Nilai kelas interval untuk aksesibilitas :

Tinggi $=-0,106$ s.d $-0,023$

Sedang $=-0,188$ s.d $-0,106$

Rendah $=-0,270$ s.d $-0,188$

Setelah didapat data kelas interval tinggi, sedang, rendah. Selanjutnya datap diklasifikasi perdesa dan pengklasifikasian indeks alfa perdesa dapat dilihat pada Tabel 1 di bawah ini.
Tabel 1. Nilai Kategori Aksesibilitas

\begin{tabular}{|l|l|c|c|}
\hline No & Kecamatan & Indeks Alfa & Kategori \\
\hline 1 & Jatimulya & -0.049 & tinggi \\
\hline 2 & Lambangsari & -0.270 & rendah \\
\hline 3 & Lambangjaya & -0.224 & rendah \\
\hline 4 & Tambun & -0.023 & tinggi \\
\hline 5 & Setiadarma & -0.049 & tinggi \\
\hline 6 & Setiamekar & -0.096 & tinggi \\
\hline 7 & Mekarsari & -0.204 & sedang \\
\hline 8 & Tridayasakti & -0.219 & rendah \\
\hline 9 & Mangunjaya & -0.079 & tinggi \\
\hline 10 & Sumberjaya & -0.220 & rendah \\
\hline
\end{tabular}

Berdasarkan tabel diatas mendapatkan indeks alfa dan menghasilkan nilai kategori rendah, sedang, dan tinggi perdesa yang menunjukan nilai akseibiltas. Selanjutnya dilakukan pemetaan klasifikasi pada arcgis untuk memudahkan desa-desa yang memiliki nilai aksesibilitas tinggi, sedang, dan rendah dengan mewarnai setiap desa menurut nilai aksesibilitasnya masing-masing. Data tersebut dapat dilihat pada Gambar 4 dibawah ini.

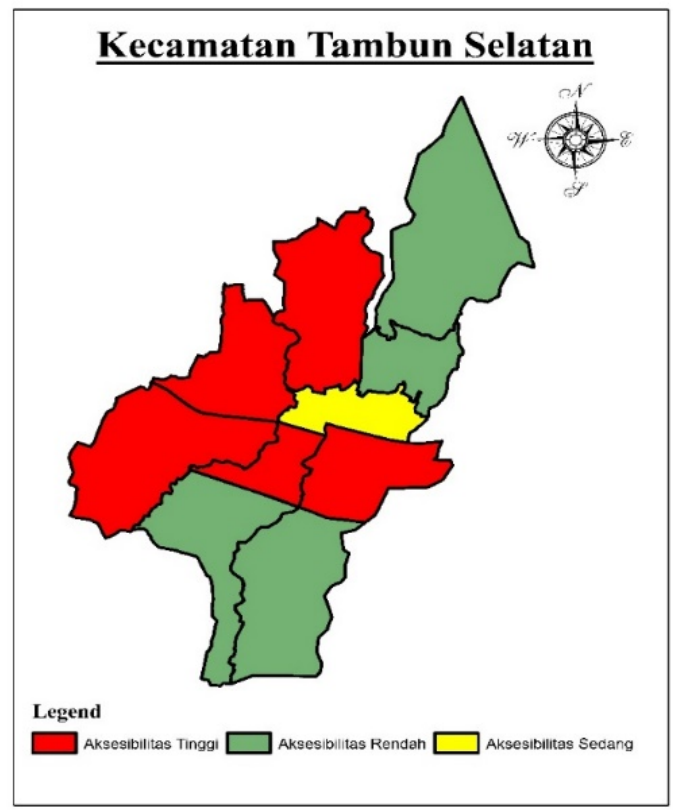

Gambar 4. Pengklasifikasian indeks alfa

Dari hasil diatas tabel 1 didapatkan bahwa desa Tambun memiliki aksesibilitas paling tinggi dengan nilai -0,023 yang menunjukan desa tambun menjadi desa yang paling mudah di akses dari luar desa dan desa Lambangsari memiliki aksesibilitas paling rendah dengan nilai $-0,270$.

\section{Analisis perkembangan wilayah}

Perhitungan skalogram dijabarkan dalam tabel yang berisi fasilitas fasilitas sarana \& prasarana per desa. Adanya fasilitas sarana dan prasarana pada setiap kecamatan ditandai dengan angka "1" sedangkan angka "0" menunjukkan kecamatan yang tidak memiliki 
fasilitas. Tabel tersebut dijumlahkan secara horizontal dan vertikal. Dalam perhitungan ini fasilitas-fasilitas di kecamatan Tambun Selatan dihitung dan di jumlahkan.

Tahap selanjutnya dari analisis skalogram adalah mengkonversi seluruh fasilitas yang ada ke dalam angka (1) dan fasilitas yang tidak ada ke dalam angka (0), kemudian menjumlahkan seluruh fasilitas berdasarkan baris dan kolom dan menetukan bobot dari setiap desa dengan cara :

$$
\text { Bobot Skalogram }=\frac{\text { Sentralitas }(100)}{\text { Jumlah Fasilitas }}
$$

Tahap selanjutnya adalah menentukan bobot dari setiap desa berdasarkan perhitungan diatas, dan didapatkan hasil bahwa terdapat 3 kelas (orde) pada kecamatan Tambun Selatan. Sebelum menetukan urutan orde disetiap desa, perlu diketahui range untuk masing-masing orde. Perhitungan orde dapat dilakukan dengan cara :

$$
\text { range }=\frac{\text { Nilai Tertinggi }- \text { Nilai Terendah }}{\text { Jumlah Orde }}
$$

Berikut perhitungannya :

$$
\begin{aligned}
& \text { range }=\frac{\text { Nilai Tertinggi }- \text { Nilai Terendah }}{\text { Jumlah Orde }} \\
& \text { range }=\frac{266,94-115}{3} \\
& \text { range }=50,56
\end{aligned}
$$

Dari perhitungan diatas, didapatkan hasil range untuk masing-masing orde pada Tabel 2 sebagai berikut :

Tabel 2. Nilai Range

\begin{tabular}{|l|ccc|}
\hline Range & \multicolumn{3}{|c|}{50.65} \\
\hline Hierarki 1 & 216.29 & - & 266.94 \\
Hierarki 2 & 165.65 & - & 216.29 \\
Hierarki 3 & 115.00 & - & 165.65 \\
\hline
\end{tabular}

Selanjutnya mengklasifikasikan berdasarkan range yang telah didapat pada setiap desa dan dapat dilihat pada Tabel 3 sebagai berikut :

Tabel 3. Klasifikasi Range Perdesa

\begin{tabular}{|c|c|c|}
\hline No. & Desa & Klasifikasi \\
\hline$(1)$ & $(2)$ & $(3)$ \\
\hline 1 & Jatimulya & Hierarki 1 \\
\hline 2 & Lambangsari & Hierarki 2 \\
\hline 3 & Lambangjaya & Hierarki 3 \\
\hline 4 & Tambun & Hierarki 1 \\
\hline 5 & Setiadarma & Hierarki 1 \\
\hline 6 & Setiamekar & Hierarki 1 \\
\hline 7 & Mekarsari & Hierarki 2 \\
\hline 8 & Tridayasakti & Hierarki 2 \\
\hline
\end{tabular}

\begin{tabular}{|c|c|c|}
\hline No. & Desa & Klasifikasi \\
\hline$(1)$ & $(2)$ & $(3)$ \\
\hline 9 & Mangunjaya & Hierarki 1 \\
\hline 10 & Sumberjaya & Hierarki 2 \\
\hline
\end{tabular}

Nilai Hierarki pada perhitungan diatas menunjukan identifikasi fasilitas yang ada pada setiap desa pada kecamatan tambun selatan dimana Hierarki 1 menunjukan layanan desa tersebut tinggi yang menjadi faktor indikasi perkembangan wilayah dibandingkan dengan desa yang lain di kecamatan tersebut, seperti desa jatimulya dan tambun. Hierarki 2 yaitu desa Lambangsari dan Sumberjaya menujukan pada desa tersebut memiliki fasilitas yang cukup tetapi tidak memiliki fasilitas yang sentral seperti perguruan tinggi dan bukan menjadi pusat layanan pada kecamatan tambun selatan. Hierarki 3 menunjukan fasilitas pada desa tersebut tidak lengkap atau desa tersebut tidak menjadi pusat layanan dari kecamatan tambun selatan. Setiap orde yang menunjukan nilai Hierarki sangat berhubungan erat dengan perkembangan wilayah pada kecamatan tersebut dibidang fasilitas atau infrastruktur.

Setelah mendapatkan dua data indeks alfa dan skalogram yang diperlukan, selanjutkan menghitung hubungan korelasi, dan akan dijelaskan sebagai berikut.

3. Perhitungan hubungan korelasi

Perhitungan data korelasi data dilihat pada Tabel 4 dibawah ini.

Tabel 4. Hasil Indeks Alfa Dan Skalogram

\begin{tabular}{|c|c|c|c|}
\hline No. & Kecamatan & $\begin{array}{c}\text { Index } \\
\text { Alfa (x) }\end{array}$ & $\begin{array}{c}\text { Skalogram } \\
(\mathrm{y})\end{array}$ \\
\hline 1 & Jatimulya & -0.049 & 221.110 \\
\hline 2 & Lambangsari & -0.270 & 196.110 \\
\hline 3 & Lambangjaya & -0.224 & 115.000 \\
\hline 4 & Tambun & -0.023 & 266.940 \\
\hline 5 & Setiadarma & -0.049 & 216.110 \\
\hline 6 & Setiamekar & -0.096 & 249.440 \\
\hline 7 & Mekarsari & -0.204 & 209.440 \\
\hline 8 & Tridayasakti & -0.219 & 126.110 \\
\hline 9 & Mangunjaya & -0.079 & 228.610 \\
\hline 10 & Sumberjaya & -0.220 & 171.110 \\
\hline & Jumlah & -1.433 & 1999.980 \\
\hline
\end{tabular}

Pengklasifikasi nilai $r$ dalam penelitian ini menggunakan kriteria keeratan hubungan Guilford 1956, yaitu :

- Nilai $r<0,2 \quad$ : Hubungan sangat kecil

- Nilai $r 0,2<X<0,4$ : Hubungan yang kecil

- Nilai $r 0,4<X<0,7$ : Hubungan cukup erat 
- Nilai $r 0,7<X<0,9$ : Hubungan yang erat

- Nilai $r 0,9<X<1,0$ : Hubungan yang sangat erat

- Nilai $r$ 1,0 : Hubungan yang sempurna

Untuk mengetahui nilai $r$ dengan data-data yang sudah diketahui, selanjutnya menggunakan aplikasi excel dan dapat dilihat pada Gambar 5 dibawah ini :

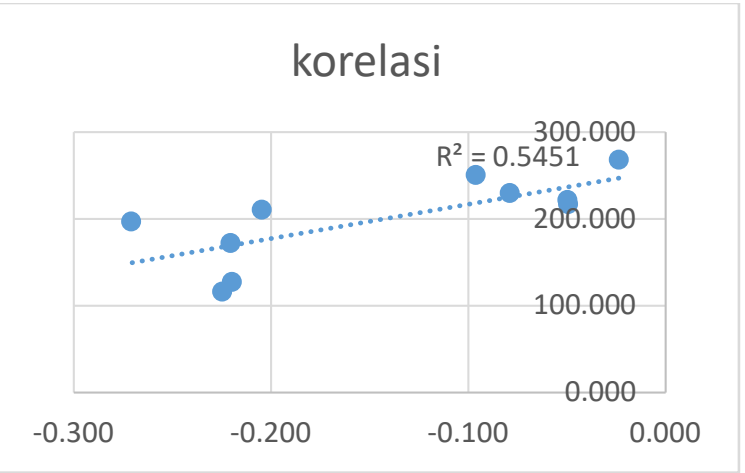

Gambar 5. Grafik nilai R

Dari data hasil Gambar 5 diatas mendapatkan nilai $\mathrm{R}^{2}$ $=0.5451$ sehingga nilai $R^{2}$ menjadi $\sqrt{0.5451}=0.738$.

Berdasarkan output (hasil) perhitungan antara aksesibilitas wilayah dan perkembangan wilayah dapat diketahui bahwa nilai korelasi antara dua variabel ini adalah sebesar 0.738 . Angka tersebut menunjukkan bahwa hubungan antara dua variabel ini termasuk dalam kategori hubungan erat karena nilai $r$ diantara nilai $0.7-0.9$.

\section{KESIMPULAN}

Desa yang memiliki nilai indeks alfa atau aksesibilitas paling tinggi yang ada di kecamatan Tambun Selatan adalah desa Tambun dengan nilai indeks alfa -0,023. Desa Tambun memiliki Jumlah ruas jalan sepanjang 6,6 kilometer, dengan 10 titik simpul yang ada di wilayah ini merupakan yang paling sedikit di antara desa lain. Namun hal ini seimbang dengan jumlah subgraf atau wilayah dusun yaitu 3 kelurahan. Hal ini menjadi faktor mengapa nilai aksesibilitas di wilayah ini menjadi yang paling tinggi diantara desa-desa lainnya. Sedangkan untuk desa dengan nilai aksesibilitas paling rendah ialah desa Lambangsari. Desa Lambangsari merupakan desa dengan jumlah ruas jalan sepanjang 10,6 kilometer dan mempunyai 28 titik simpul.

Desa yang memiliki nilai perkembangan wilayah paling tinggi dibandingkan dengan desa lain di Kecamatan Tambun Selatan adalah desa Tambun dengan nilai range 266,94 dan mendapatkan kategori hierarki 1. Sebagai pusat pelayanan kota, kecamatan ini memiliki sarana dan prasarana yang memadai, meliputi fasilitas pendidikan, kesehatan, perdagangan, dan peribadatan. Sedangkan untuk kecamatan dengan nilai perkembangan wilayah paling rendah adalah desa Lambangjaya dengan nilai range 115 dan mendapatkan kategori hierarki. Salah satu faktor yang mempengaruhi perkembangan wilayah desa ini adalah karena faktor jarak yang cukup jauh dari pusat kecamatan Tambun Selatan. Indikator penilaian perkembangan wilayah yaitu fasilitas pendidikan, kesehatan, perindustrian dan perdagangan.

Berdasarkan analisis korelasi diketahui bahwa terdapat hubungan yang erat antara aksesibilitas wilayah dengan perkembangan wilayah. Dengan mendapatkan nilai yang cukup signifikan yaitu $r=0,738$ diantara indikator $0,7-0,9$.

\section{UCAPAN TERIMA KASIH}

Dalam menyelesaikan Tugas Akhir ini, penulis banyak mendapatkan bantuan dan dorongan baik yang berupa moril maupun materil dari berbagai pihak. Untuk itu penulis mengucapkan terima kasih banyak yang tiada terhingga kepada:

1. Penghargaan yang luar biasa penulis sampaikan kepada kedua orang tua tersayang dan keluarga tercinta, atas segala dukungan dan motivasi serta Doa dan kasih sayang yang telah diberikan.

2. Bapak Dr. Prima Jiwa Osly, ST. Msi. dan Irfan Ihsani, ST. MT selaku dosen pembimbing I dan dosen pembimbing II yang telah sangat membantu penulis dalam menyelesaikan Tugas Akhir ini atas keikhlasan dalam membimbing, memberikan ilmu dan nasihat, serta dorongan kepada penulis dalam menyelesaikan Tugas Akhir ini.

3. Bapak Ir. Akhmad Dofir, MT. IPM, Ibu Niken Warastuti, ST. MT selaku Ketua dan Sekretaris, Seluruh Dosen dan Staff akademik Program Studi Teknik Sipil Fakultas Teknik Universitas Pancasila, yang senantiasa memberikan dorongan dan semangat serta ilmu yang telah diberikan selama menjalani perkuliahan, sehingga penulis dapat menyelesaikan Tugas Akhir ini dalam waktu yang telah ditentukan.

4. Semua pihak yang telah memberikan bantuan baik secara langsung maupun tidak langsung, yang tidak dapat penulis sebutkan satu persatu.

\section{REFERENSI}

Aminah, S. (2009) 'Transportasi Publik dan Aksesibilitas Masyarakat Perkotaan', Q-Journal, Vol 20(1), pp. 1-13. Available at: http://journal.unair.ac.id/filerPDF/Transportasi Publik dan Aksesibilitas.pdf.

Budianta, A. (2010) 'Pengembangan Wilayah Perbatasan Sebagai Upaya Pemerataan Pembangunan Wilayah Di Indonesia', SMARTex, 8, p. 1.

Istikhomah, A. A. et al. (2013) Analisa Sistem Pusat Pelayanan Pemukiman Di Kabupaten Magelang Dengan Analisa SKalogram Dan Indeks Sentraitas Marshall.

Kurnianingsih, N. A. and Rudiarto, I. (2014) 'Analisis Transformasi Wilayah Peri-Urban pada Aspek Fisik dan Sosial Ekonomi (Kecamatan Kartasura)', Jurnal Pembangunan Wilayah \& Kota, 10(3), p. $265 . \quad$ doi: 
10.14710/pwk.v10i3.7784.

Kusrini, Suharyadi and Hardoyo, S. R. (2011) 'Perubahan Penggunaan Lahan Dan Faktor Yang Mempengaruhinya Di Kecamatan Gunungpati Kota Semarang', Majalah Geografi Indonesia, 25(1), pp. 25-42.

Manullang, O. R. (2006) 'Pengaruh Aksesibilitas Terhadap Perkembangan Wilayah Secara Sprawl Di Kota Semarang'.

Munandar, A. (2010) Analisis Ekonomi Dan Potensi Pengembangan Wilayah Kecamatan Gemolong, Kabupaten Sragen.

Prasetya, D. T. R. I. (2009) 'Di Kabupaten Kudus Propinsi Jawa Tengah'.

Republic of Indonesia (2006) 'Road: Republic of Indonesia Government Regulation No 34 2006', p. 92. doi: 10.1017/CBO9781107415324.004.

Riadi, A. (2015) Analisis perkembangan wilayah dan arahan prioritas penanganan jaringan jalan di kabupaten bogor.

Sukabumi, K. et al. (2014) 'Panjang Jalan Provinsi Tahun 2013 - 2014 Panjang Jalan Provinsi Dalam Kondisi Mantap Dan Tidak Mantap Provinsi Jawa Barat Tahun 2013-2014 ( Satuan: km ) Panjang Jalan Provinsi Tahun 2013 - 2014 Panjang Jalan Provinsi Dalam Kondisi Mantap Dan Tidak Mantap', 2014(98), pp. 3-6.

Sumardi, S. H. T., Franklin, P. J. . and Makainas, I. (2015) 'HUBUNGAN Aksesibilitas Terhadap Tingkat Perkembangan Wilayah Kecamatan Di Kota Tomohon'.

Terpercaya, D. S. (2016) Kecamatan Tambun Selatan Dalam Angka 2016.

Widodo, E. K. O. (2007) 'Program Studi Perencanaan Wilayah dan Kota'. 